\title{
Does Being Located in Less-Favored Areas Weaken the Profitability of Polish Farm Households? Empirical Evidence
}

\author{
Radosław Pastusiak ${ }^{1 *}$, Magdalena Jasiniak ${ }^{1}$, Michał Soliwoda $^{2}$, Joanna Stawska $^{3}$ \\ ${ }^{1}$ Corporate Finance Department, Faculty of Economics and Sociology, University of Łódź, Łódź, Poland \\ ${ }^{2}$ Institute of Agricultural and Food Economics, National Research Institute, Warsaw, Poland \\ ${ }^{3}$ Central Banking and Financial Intermediation Department, Faculty of Economics and Sociology, \\ University of Łódź, Łódź, Poland
}

Received: 7 December 2017

Accepted: 3 March 2018

\begin{abstract}
Detailed analysis of Hill [1] based on EU FADN data indicate that the level of "incomes of farms in LFAs was lower than those in non-LFAs, even after including the special payments that the former receive." The following question arises as to whether being located on less-favored areas may alter significantly the financial efficiency of farms and whether it is possible to identify such measures that would improve financial efficiency at a farm level and preserve the environmental value of the LFA and implement sustainable development policies. The article proposes an analysis of profitability according to criteria regarding being located on LFA, taking into account the peculiarities of production orientation. This is an important issue, not only from a scientific point of view but also an important element for agricultural policy and the issue of subsidies to agricultural holdings located in areas of environmental constraints. We confirmed that in Poland in 2009-2014 the farms located on LFAs significantly differentiate the financial efficiency of farms and are significantly less profitable assets and use financial resources less effectively than farms located in favorable areas. We also proved that farms located on LFAs that specialize in crop productions are described by the highest profitability.
\end{abstract}

Keywords: less favorable areas, farm household profitability, environmental constraints

\section{Introduction}

Environmental conditions are determinants of farm productivity and, consequently, their profitability. The occurrence of environmental constraints understood as constraints arising both from the land formation and ecological protection can significantly weaken farm

*e-mail: rpastusiak@uni.lodz.pl productivity, development, and additional costs for plant and livestock production due to ecosystem protection [2]. Not only access of farmers to production factors (land, and capital) and technologies, but also existing environmental constraints may affect the economic results of farms, consequently their financial condition, described by profitability [2-3]. A plethora of empirical findings related to the agricultural sector proved that exploring this complex relationship, ID EST existing environmental constraints vs. financial results of farms 
[4-8]. In particular, being located in less favored areas (LFAs) refers to a set of 'natural handicaps' in farming ("difficult climatic conditions, steep slopes in mountain areas, or low soil productivity in other less-favored areas," European Commission [9]). Moreover, "due to the handicap of farming, there is a significant risk of agricultural land abandonment and thus a possibility of loss of biodiversity, desertification, forest fires, and the loss of highly valuable rural landscape" [9], focusing on farms located on LFAs is of great importance.

Farm households on LFAs benefit from LFA payment schemes within Rural Development Programmes (RDPs). Hence, ongoing monitoring of income and profitability situations is helpful for ex-post evaluation and redesigning particular schemes in RDPs. Detailed analyses of Hill [1] based on EU FADN data indicated that the level of "incomes of farms in LFAs was lower than those in non-LFAs, even after including the special payments that the former receive." The following question arises whether the location on less-favored areas may differ significantly the financial efficiency of farms and whether it is possible to identify such measures that would improve the financial efficiency at a farm level and, on the other hand, preserve the environmental value of the LFA and implement sustainable development policies. Being located on an LFA has been treated as one of the external restrictions.

Profitability (measured by rates of return, ROE returns on equity, ROA - returns on assets) relates to the ratio of net farm income (adjusted by own labor cost) to economic categories, respectively assets, capital equity, or sales. Exploring statistical dependencies related to profitability as the proxy for financial efficiency sheds lights on the utilization of production factors. The calculation of "farm net income" ("family farm income") as the broad economic category, including the impact of subsidies (SE600 the balance current subsidies and taxes) with some adjustments (plus bank interest) is a more detailed proxy for the financial performance of farms.

There are no studies in the literature that would relate broadly to the relationship of environmental constraints to competitiveness. Many authors have referred only to limited aspects of this issue because estimating the impact of environmental regulation on the Common Agricultural Policy (CAP, a set of public policies related to the agricultural sector and rural areas that has partially been uninformed at a country level) on the competitiveness of EU agriculture is difficult [10]. So far, only a limited number of studies in this area have addressed environmental constraints in the context of assessing the effectiveness of farms. The article fills a research gap in this area and proposes an analysis of profitability according to criterion on location on LFA, taking into account the peculiarities of production orientation (crop/livestock and mixed production). This is an important issue, not only from a scientific point of view but also an important element for agricultural policy and the issue of subsidies to agricultural holdings located in areas of environmental constraints. This problem is particularly important for the Polish economy, where the agricultural sector is of great social and economic importance and the share of LFAs in agricultural land is significant $(>50 \%)$.

The main aim of this paper is to assess the influence of the location of family farm households on LFAs as a factor differentiating their profitability. Our analyses include:

1) Presenting descriptive statistics for profitability of farm households located both on LFA and non-LFA

2) Verifying differences between profitability indicators between production specialties: farms located and not located on LFAs

3) Exploring dependencies between the type of less favored areas and fulfilling inequality $\mathrm{ROE}>\mathrm{ROA}$

4) Presenting the share of entities that fulfil inequality ROE $>$ ROA in group of LFA and non-LFA farm households

\section{Literature Review}

Areas defined as less favored have some important issues that affect strongly agricultural production and activity. Natural handicaps like difficult climatic conditions, steep slopes in mountain areas, or low soil productivity increase operational risk in farming. Additionally, these areas are often an important part of cultural heritage. The LFA scheme was included in the Rural Development Policy for 2007-2013, which aims to improve the environment and countryside by supporting sustainable land management. The objective of the LFA scheme is described in Council Regulation (EC) No. 1698/2005 (Recital 33) as follows: "Natural handicap payments in mountain areas and payments in other areas with handicaps should contribute, through continued use of agricultural land, to maintaining the countryside, as well as to maintaining and promoting sustainable farming systems." This strongly highlights the environmental priorities in co-funding farming in less favorable areas.

The main challenges of agricultural development in areas with environmental constraints might be categorized into biophysical and socioeconomic issues and additionally as the interaction between these two categories. The biophysical constraints have a stronger impact on LFAs than on productive areas. Farm growth might be limited here by short growing periods due to seasonal drought, flood, or stresses caused by unfavorable soil physical properties like low soil depth, salinity, poor drainage or water-holding capacity or susceptibility to erosion. As a result, on LFAs the yield premium from farm technology adoption is usually lower, while the seasonal yield variability is higher in comparison to favorable areas. Socioeconomic factors that limit the productivity of farms located in LFAs are mainly related to high transaction costs associated with geographic insulation, imperfect markets, poor infrastructure, and public services. Additionally, farm 
households in LFAs are heterogeneous in terms of biophysical and socio-economic conditions. They have different access to markets, different land qualities, etc. This results in difficulties with the equal adaptation of certain solutions to improve technologies or employment [11].

So far, studies have mainly focused on environmental policies implemented on LFAs to protect environment natural sources and promote proper land management [e.g., 12-14]. This affects many categories like price and market policies, public service and investment, institutions, and governance. The main actions concentrate on investments in infrastructure, human capital, and technology in order to enhance the competitiveness of these areas and improve market access [15]. This directly influences rural development in LFAs. However, as De Janvry et al. [16] concluded, the problem is not only in the proper understanding of rural development issues but also in difficulties in identifying effective and profitable activities.

There are a plethora of empirical studies on various aspects of farming on LFAs in EU countries, inter alia [4-8]. This indicates that farms dealing with environmental restrictions are of great interest to both scientists and policymakers.

Journeaux [17] pointed out that environmental constraints affect farming mainly in two ways: by increasing costs and/or decreasing profitability and significantly reducing opportunity to intensify production, both in situ and via land use change. Both determine the land value, which has further consequences, e.g., in evaluating the credit risk of farming and household opportunities to develop.

Sojkova, Kropkova, and Benda [18] studied Slovakian agricultural farms. Researchers compared productive farms with those located on LFAs in terms of technical efficiency. Authors expected to find significant differences between productive and nonproductive regions and discovered its determinants. It was observed that during the time period analyzed, technical efficiency improved in both groups; however, there were no significant differences between them despite 2005, when the higher level of variability in technical efficiency in farms located in production regions was observed.

Andreson and Keatley [19] formulated the business model to optimize beef and sheep production systems for an LFA farm in Northern Ireland. They indicated three major aspects of farming on LFAs, like production costs, marketing, and agriculture policy. As Authors suggested, regions with environmental constraints are characterized by the high risk of losing agriculture activity - especially those with the greatest physical challenges.

On the other hand, Pender and Hazell [20] mentioned that less favored areas often have an absolute disadvantage in producing many types of crops compared to the favored areas (i.e., LFA productivity is lower than in favored areas). Typically, however,
LFAs have a comparative advantage in some types of agricultural production or in non-farm activities. This means that production can be profitable with the alternative use of land and labor force in these areas. The varied situation in LFAs can allow them to use their different comparative advantages provided that the necessary investments in infrastructure and institutions are made. There is growing evidence to suggest that investments in LFAs can contribute to relatively high rates of return and reduce poverty in some countries.

Uematsu, Khanal, and Mishra [21] underlined that farmland values are influenced not only by agricultural production but also by several other economic and environmental factors. Their quantile regression analysis for USA farmland data suggests that natural amenity is positively correlated with farmland values and its impact is often more pronounced at the higher price range of farmland.

\section{Material and Methods}

LFAs in Poland

In Poland, the agricultural sector plays an important role not only in economics but also socially. Rural areas in Poland account for $93.1 \%$ and are inhabited by 15.1 million people, representing $39.2 \%$ of the total population [22]. As Poland joined the European Union, Polish farms had to change the way they functioned and adjust to new regulations [23].

According to Council Regulation (EC) No. 1257/1999 changed by Council Regulation (EC) No. 1783/2003, LFA areas include mountain areas (Article 18), lowland areas (Article 19), and areas with specific handicaps (Article 20) (see Table 1).

In Poland, $92.6 \%$ of LFAs are lowland areas (see Table 1). The LFA payments cover nearly 11 million hectares, which constitutes about $60 \%$ of agricultural land in Poland [24].

Major problems that are highlighted in the case of Polish LFAs are as follows:

- Limitations related to topographical constraints and/ or poor soil quality.

Table 1. Share of less-favored areas in Poland.

\begin{tabular}{|c|c|c|}
\hline \multirow{2}{*}{ Specification } & \multicolumn{2}{|c|}{ Agricultural land } \\
\cline { 2 - 3 } & \multicolumn{2}{|c|}{ Categories* } \\
\hline Art. 18 & Mountains & 2,3 \\
\hline Art. 19 & Lowlands type I and II & 92,6 \\
\hline Art. 20 & Areas with specific handicaps & 5,3 \\
\hline Total LFA in Poland & \multicolumn{2}{|c|}{$\mathbf{1 0 0 , 0 0}$} \\
\hline
\end{tabular}

* \% of categories

Source: Our own elaboration based on [24] 
- Small area of farmlands and small scale of production.

- Low production efficiency and low labor productivity in the majority.

- Increasing depopulation, especially in the region of the Carpathians, which also occurs alongside loosening family, social, and cultural ties.

- Changes in demographic structure, as with the significantly aging population in Sudety or increasing feminization.

- The absence of successors in the case of family farms [24].

There is also a strong positive correlation between areas classified as LFAs and areas of particular environmental value, i.e., $80 \%$ of Nature 2000 sites, then $72 \%$ of permanent agricultural land and $67 \%$ of agricultural land reported to the agri-environment program are within the LFA. The objectives of the LFA in Poland include: ensuring the continuity of agricultural land use and thus maintaining the vitality of rural areas, preserving the landscape values of rural areas, and promoting environmentally friendly farming [22]. The LFA support system allows for the use of the allocated funds to increase agricultural incomes or to counter depopulation of these areas. In addition, LFA subsidies are an important opportunity for owners of particularly medium-sized farms who, thanks to EU support, can grow their farms [25].

In the case of high-value nature areas, Sutkowska et al. [26] concluded that they primarily served a social function. This type of land is characterized by the lowest consumption of the means of production and the lowest livestock density. The highest share of cereals in the crop structure influences the gradual decrease of the soil's organic matter and nutrients. Authors also discussed the alternatives for this area development in non-agricultural activities, mainly agrotourism, which provides better land use and protection. However, these issues are another research area for discussion.

Nehring et al. [27] checked on what determined the drivers of the economic financial success of U.S. cow-calf operations using 2008 farm-level data. The study found that one of the main drivers of return to equity (ROE) is the region, where a number of regional differences are noted for profitability, asset efficiency, and solvency (with the North Central and Northern Plains regions having the highest returns on equity).

The profitability of agricultural farms is probably affected by compensation payments to farm owners under the Rural Development Programme (RDP). The Common Agricultural Policy (CAP) of the EU exposes the role of farms in the management of natural space in rural areas. The purpose of agri-environmental payments is to provide farmers with compensation for the additional costs and lost revenue that results from the use of environmentally friendly farming practices. On the other hand, in the case of payments for LFA, only a partial focus is placed on activating farms to ensure the greater supply of public goods. The aim of
Table 2. Rates of payment for particular LFA types in 2014-2020.

\begin{tabular}{|c|c|c|}
\hline LFA type & & Rate of payment* \\
\hline \multirow{2}{*}{ Lowland } & Lowlains & 450 \\
\cline { 2 - 3 } & Lowland zone II & 179 \\
\hline \multirow{2}{*}{ Specific } & 264 \\
\hline \multicolumn{2}{|c|}{ Sone I } & 264 \\
\hline
\end{tabular}

* in (PLN/ha/year)

Source: Based on ARiMR data [29]

this action is to compensate for the development of farms located in areas where agricultural production is impeded due to adverse environmental conditions. As mentioned previously, these subsidies are intended to compensate farmers for losing their income because of natural handicaps and should counteract the depopulation of rural areas and the loss of their agricultural character [28].

The average Polish LFA payment rate for 2007-2014 was about $60 \%$ of the average LFA rate in EU, while the rates for the years 2014-2020 differ slightly from the ones in the previous program (see Table 2), except for mountains LFA payment rate, which increased by about $40 \%$ [24].

Monitoring the financial performance of farms receiving agri-environmental payments included standard inequalities (ROE $>$ ROA) for the period 2010-2014. Observing particularly the years 2010 and 2014, it was noted that the benchmark inequality in ROE $>$ ROA analyzed was satisfied for an average of over $40 \%$ of all farms receiving agri-environmental payments in the beginning and the end of the period. On the other hand, for agricultural farms receiving LFA payments, this inequality has been met for on average more than $30 \%$ of all farms [24].

According to Kopiński [30], for low-income farms in Poland characterized by mainly multi-directional farms, direct payments and LFA payments are of great importance. They are a stabilizing factor and are decisive in determining the viability of these farms. Another major group benefiting from subsidies is specialized plant farms because subsidies are most important for farms representing the land-intensive type of production intensification.

\section{Data and Methodology}

Our paper presents a comparative analysis of profitability between farm households located on productive areas and less favored areas with consideration of its subgroups. Authors verify the following hypotheses:

H1: In Poland, farms located on LFAs are significantly less profitable than farms located in favorable areas. 
LFA households have to force with limitations due to the possibilities of effective use of assets and resources. The financial results of farming here are lower than in environmentally friendly areas. In Poland, the majority of agricultural lands is supported by agri-environment programs, therefore, the question is whether the LFA farms are much less effective than non-LFA, and whether these differences are statistically confirmed. Results in this area are important for the directions of agriculture policy instruments.

H2: LFA farms specializing in crop production were described by the highest (statistically significant) profitability in comparison to other farms.

The Polish system of farm subsidiaries is differentiated and depends on product type. Farms that are specialized in crop production are supported by higher subsidies than others. As a consequence, it may be expected that in areas with environmental constraints, these households will be more effective. On the other hand, crop production is more sensitive to environmental changes and the effectiveness of crop production depends to a wider extent on geographic and climate determinants.

H3: Due to environmental constraints, farms located on LFA do not use make full use of their resources.

Due to environmental constraints, farms are not able to use the whole potential of their resources, which is possible in areas of a friendly environment. It has a consequence in household financial management and influences the possibility of attracting external capital and achieving benefits from leveraging effects and tax shields.

Research is based on financial data of individual farm households collected from the Farm Accountancy Data Network (FADN). FADN is one of the tools supporting the programming and implementation of Common Agricultural Policy tasks. Data are used primarily for evaluating yearly incomes of farm households in the European Union, farm activity analysis, and evaluation of agricultural policy effects. Farm households' classification is based on two main criteria: economic size and agriculture type. The conomic size of farms is determined by the sum of standard production obtained from all activities on the farm. Farm type is defined by the share of standard production from the individual groups of agricultural activity in the total standard output of the farm, which is defined as the average of 5 years of production value of a given plant or production activity obtained from 1 ha, or 1 animal within 1 year in the regions' average conditions [31].

The financial efficiency of farms was measured by the following indicators: ROE, ROA for the years 2009-2014. Additionally, equation ROE $>$ ROA was measured.

The inequality ROE $>$ ROA has several implications from the perspective of farm financial efficiency. The systems of inequalities may be used for rationalizing financial management processes. In line with the Du Pont decomposition, ROE and ROA are strongly interconnected. As indicated in Equation (1) below, ROE may be treated as:

$$
\mathrm{ROE}=\mathrm{ROA} \times(\mathrm{A} / \mathrm{E})
$$

...where:

$\mathrm{ROE}$ - return on equity, ROA - return on assets

$\mathrm{A} / \mathrm{E}$ - assets/equity (so-called equity multiplier)

Profitability of assets (ROA) that depend on sales effectiveness/efficiency and asset turnover may be greater than sales profitability. Moreover, a surplus between the rate of return on equity (ROE) and rate of assets (ROA) reflects the share of liabilities in firm financing. The farm uses financial leverage when ROE $>$ ROA. This may have various implications related to a higher exposure of this entity on a financial risk [32]. For example, Stefani et al. [33] proved empirically a negative impact of debt-to-asset ratio to technical efficiency. Langemeier [33] found that "leverage increases both variabilities in returns and downside risk." As a result, a risk-averse farm operator will take a relationship between $\mathrm{ROE}$ and ROA before taking credit or loan [34].

The most important aspect in the assessment of farm efficiency is profitability analysis, which indicates the effective use of farm resources, including assets and financial resources. This also refers to farms where adjusted farm income may be treated as an equivalent of an entrepreneurial profit. The positive profitability (ROE and ROA) should reach such a level that on the one hand compensates for the risk and, on the other hand, makes strategic gains possible for the entity objectives, also in the longer term $[32,35]$.

The whole sample was purged from deficiencies and outliers (outliers are defined as observations below Q1-1,5*IQR and above Q3+1,5*IQR). All types of farms according to the area of production and economic size were taken into consideration. Results were verified by the Mann-Whitney $U$ and The Kruskal-Wallis tests.

Table 3. Sample size in particular years and share of farms receiving LFA payments in the total number of farms located on LFAs.

\begin{tabular}{|c|c|c|c|}
\hline \multirow{2}{*}{ Year } & \multicolumn{2}{|c|}{$\begin{array}{c}\text { Number } \\
\text { of households }\end{array}$} & \multirow{2}{*}{$\begin{array}{r}\text { Percentage of farm receiving } \\
\text { LFA payments } \\
\text { (located on LFAs) }\end{array}$} \\
\cline { 2 - 3 } & LFA & non-LFA & 92,3 \\
\hline 2009 & 5710 & 4507 & 91,3 \\
\hline 2010 & 5818 & 4482 & 89,1 \\
\hline 2011 & 5752 & 4419 & 86,8 \\
\hline 2012 & 5715 & 4432 & 90,7 \\
\hline 2013 & 6446 & 4960 & 88,3 \\
\hline 2014 & 6411 & 5034 & \\
\hline
\end{tabular}

Source: Own elaboration 
Table 4. Descriptive statistics.

\begin{tabular}{|c|c|c|c|c|c|c|c|c|c|c|c|c|}
\hline \multirow{2}{*}{\multicolumn{2}{|c|}{ Description }} & \multicolumn{2}{|c|}{ Average } & \multicolumn{3}{|c|}{ Median } & \multicolumn{2}{|c|}{ Min } & \multicolumn{2}{|c|}{ Max } & \multicolumn{2}{|c|}{ SD } \\
\hline & & \multirow{2}{*}{$\begin{array}{l}\text { LFA } \\
-1,27\end{array}$} & \multirow{2}{*}{$\begin{array}{c}\begin{array}{c}\text { non - } \\
\text { LFA }\end{array} \\
-0,81\end{array}$} & \multirow{2}{*}{$\begin{array}{l}\text { LFA } \\
-1,32\end{array}$} & \multirow{2}{*}{$\begin{array}{l}\text { non - } \\
\text { LFA } \\
-0,68\end{array}$} & \multirow{2}{*}{$\begin{array}{c}\text { p-value* for } \\
\text { UM-W test }\end{array}$} & \multirow{2}{*}{$\begin{array}{c}\text { LFA } \\
-18,53\end{array}$} & \multirow{2}{*}{$\begin{array}{l}\text { non - } \\
\text { LFA } \\
-18,51\end{array}$} & \multirow{2}{*}{$\begin{array}{c}\text { LFA } \\
19,01\end{array}$} & \multirow{2}{*}{$\begin{array}{c}\text { non - } \\
\text { LFA }\end{array}$} & \multirow{2}{*}{$\begin{array}{l}\text { LFA } \\
8,04\end{array}$} & \multirow{2}{*}{$\begin{array}{l}\text { non - } \\
\text { LFA } \\
7,83\end{array}$} \\
\hline & ROA & & & & & & & & & & & \\
\hline & ROE & $-1,40$ & $-0,96$ & $-1,82$ & $-1,22$ & 0,008 & $-19,89$ & $-19,79$ & 20,32 & 20,30 & 8,98 & 8,71 \\
\hline \multirow{2}{*}{2010} & ROA & 0,58 & 1,01 & 0,74 & 1,29 & 0,000 & $-18,53$ & $-18,46$ & 19,03 & 19,06 & 6,32 & 6,45 \\
\hline & ROE & 0,64 & 1,04 & 0,54 & 1,22 & 0,000 & $-19,63$ & $-19,16$ & 20,25 & 20,33 & 6,78 & 6,89 \\
\hline \multirow{2}{*}{2011} & ROA & 0,61 & 1,60 & 0,83 & 1,83 & 0,000 & $-18,52$ & $-18,44$ & 19,05 & 18,85 & 6,64 & 6,60 \\
\hline & ROE & 0,69 & 1,68 & 0,70 & 1,72 & 0,000 & $-19,71$ & $-19,29$ & 20,31 & 20,23 & 7,11 & 7,08 \\
\hline \multirow{2}{*}{2012} & ROA & 0,41 & 1,48 & 0,59 & 1,74 & 0,000 & $-18,50$ & $-18,51$ & 18,96 & 18,84 & 6,63 & 6,72 \\
\hline & ROE & 0,43 & 1,55 & 0,34 & 1,66 & 0,000 & $-18,88$ & $-19,28$ & 20,30 & 20,32 & 7,11 & 7,20 \\
\hline \multirow{2}{*}{2013} & ROA & 0,02 & 0,69 & 0,18 & 0,92 & 0,000 & $-18,44$ & $-18,51$ & 19,07 & 18,79 & 6,42 & 6,33 \\
\hline & ROE & 0,02 & 0,70 & $-0,03$ & 0,76 & 0,000 & $-19,45$ & $-19,70$ & 20,20 & 20,28 & 6,89 & 6,80 \\
\hline \multirow{2}{*}{2014} & ROA & $-0,87$ & $-0,36$ & $-0,85$ & $-0,16$ & 0,000 & $-18,52$ & $-18,52$ & 18,94 & 18,43 & 6,29 & 6,15 \\
\hline & ROE & $-0,78$ & $-0,23$ & $-0,91$ & $-0,17$ & 0,000 & $-19,27$ & $-19,67$ & 19,94 & 20,17 & 6,65 & 6,55 \\
\hline \multirow{2}{*}{ Average } & ROA & $-0,09$ & 0,60 & 0,03 & 0,82 & 0,000 & $-18,51$ & $-18,49$ & 19,01 & 18,83 & 6,72 & 6,68 \\
\hline & ROE & $-0,07$ & 0,63 & $-0,20$ & 0,66 & 0,000 & $-19,47$ & $-19,48$ & 20,22 & 20,27 & 7,25 & 7,20 \\
\hline
\end{tabular}

Note: Results of U Mann-Whitney tests; values significant at $5 \%$ level are shaded

Source: Own elaboration

The conducted analysis has a comparative character. Farm households were classified into two major groups - farms located in LFAs and productive areas, similar in terms of sample size (see Table 3). Within the LFAs, farms located in mountains and other LFA areas were additionally selected. In terms of product type, a more detailed analysis included the comparison of profitability within the crop, livestock, and mixed production farms located in LFA and productive areas.

Finally, the sample size of LFA and non-LFA farm households were as seen in Table 3.

As presented in the table above, the vast majority of farms located on LFAs benefited from LFA payments as a Rural Development Programme measure. The minimum share of farms receiving this type of subsidy in the total number of farms located on LFAs was $86,8 \%$ (in 2012), whereas the highest share was noted in 2009 at about $92,3 \%$ of LFA farms benefited from this payment. It should be noted that there is a relatively long list of criteria of eligibility for receiving LFA payments. Therefore, farm operators receiving LFA payments should deal with decreasing payment rates. Additionally, LFA payments to an agricultural parcel included in the Agricultural Property of the Treasury is granted to a farmer who has a legal title to this parcel [29]. In fact, our analyses were focused on the issue on the location on LFAs, not the impact of LFA payments that should be explored by other research tools.

\section{Results and Discussion}

Although the sample size differs slightly in particular years, the proportion between LFA and non-LFA farms is maintained during the whole period analysed (Table 4).

As statistics show (see Table 4), the profitability of farm households located in LFAs is much lower than for farms located in productive areas. However, the range between minimum and maximum values of profitability ratios is similar in both groups of households. This suggests that the number of unprofitable farms in the case of less favorable areas is much higher, which is also confirmed by the median values.

It can be observed that there is a short-term increase in farm productivity up to 2011 - both in LFA and nonLFA farms. The tendencies are similar in both locations and probably were caused by external factors that are not strongly related to environmental handicaps.

In order to verify hypothesis H1, the Mann-Whitney $\mathrm{U}$ test and descriptive statistic as median were used (see Table 4). The Mann-Whitney $U$ test serves to verify the hypothesis of the insignificance of the differences between the medians of the studied variables in two populations, assuming that the distributions of the variables are close to each other. Hypothesis $\mathrm{H}_{0}$ means that the distributions of two populations are identical and the alternative hypothesis 
Table 5. Differences between profitability indicators between productions specialties and farms located in less-favored areas.

\begin{tabular}{|c|c|c|c|c|c|c|c|}
\hline \multirow{2}{*}{ Year } & & \multicolumn{3}{|c|}{ ROA } & \multicolumn{3}{|c|}{ ROE } \\
\hline & & $\mathrm{C}$ & $\mathrm{L}$ & M & $\mathrm{C}$ & $\mathrm{L}$ & M \\
\hline \multirow{3}{*}{2009} & $\mathrm{Me}$ & $-0,59$ & $-\mathbf{0 , 4 0}$ & $-3,74$ & $-1,07$ & $-0,84$ & $-4,41$ \\
\hline & Av & $-0,71$ & $-0,47$ & $-3,24$ & $-0,83$ & $-0,54$ & $-3,49$ \\
\hline & & \multicolumn{3}{|c|}{ chi-squared $=134,92, \mathrm{df}=2, \mathrm{p}$-value $<0,001$} & \multicolumn{3}{|c|}{ chi-squared $=127,5, \mathrm{df}=2, \mathrm{p}$-value $<0,001$} \\
\hline \multirow{3}{*}{2010} & $\mathrm{Me}$ & 2,22 & 1,05 & $-1,12$ & 2,21 & 0,87 & $-1,29$ \\
\hline & Av & 2,12 & 0,85 & $-1,17$ & 2,27 & 0,94 & $-1,23$ \\
\hline & & \multicolumn{3}{|c|}{ chi-squared $=200,59, \mathrm{df}=2, \mathrm{p}$-value $<0,001$} & \multicolumn{3}{|c|}{ chi-squared $=194,23, \mathrm{df}=2, \mathrm{p}$-value $<0,001$} \\
\hline \multirow{3}{*}{2011} & $\mathrm{Me}$ & 2,05 & 1,48 & $-1,40$ & 1,92 & 1,43 & $-1,62$ \\
\hline & Av & 1,70 & 1,27 & $-1,51$ & 1,85 & 1,38 & $-1,54$ \\
\hline & & \multicolumn{3}{|c|}{ chi-squared $=133,76, \mathrm{df}=2, \mathrm{p}$-value $<0,001$} & \multicolumn{3}{|c|}{ chi-squared $=128,38, \mathrm{df}=2, \mathrm{p}$-value $<0,001$} \\
\hline \multirow{3}{*}{2012} & $\mathrm{Me}$ & 1,82 & 1,09 & $-1,45$ & 1,74 & 0,89 & $-1,69$ \\
\hline & Av & 1,54 & 0,94 & $-1,54$ & 1,67 & 0,97 & $-1,62$ \\
\hline & & \multicolumn{3}{|c|}{ chi-squared $=191,77, \mathrm{df}=2, \mathrm{p}$-value $<2,2 \mathrm{e}-16$} & \multicolumn{3}{|c|}{ chi-squared $=186,35, \mathrm{df}=2, \mathrm{p}$-value $<0,001$} \\
\hline \multirow{3}{*}{2013} & $\mathrm{Me}$ & 0,96 & 0,94 & $-2,14$ & $\mathbf{0 , 8 3}$ & 0,78 & $-2,46$ \\
\hline & Av & $\mathbf{0 , 8 4}$ & 0,82 & $-2,28$ & 0,94 & 0,84 & $-2,43$ \\
\hline & & \multicolumn{3}{|c|}{ chi-squared $=297,83, \mathrm{df}=2, \mathrm{p}$-value $<2,2 \mathrm{e}-16$} & \multicolumn{3}{|c|}{ chi-squared $=296,14, \mathrm{df}=2, \mathrm{p}$-value $<2,2 \mathrm{e}-16$} \\
\hline \multirow{3}{*}{2014} & $\mathrm{Me}$ & $-0,56$ & $-0,03$ & $-2,76$ & $-0,60$ & $-0,03$ & $-2,84$ \\
\hline & Av & $-0,64$ & 0,06 & $-3,04$ & $-0,52$ & $\mathbf{0 , 1 8}$ & 3,05 \\
\hline & & \multicolumn{3}{|c|}{ chi-squared $=273,62, \mathrm{df}=2, \mathrm{p}$-value $<<0,001$} & \multicolumn{3}{|c|}{ chi-squared $=270,24, \mathrm{df}=2, \mathrm{p}$-value $<2,2 \mathrm{e}-16$} \\
\hline
\end{tabular}

Note: $\mathrm{C}$ - crop production, $\mathrm{L}$ - livestock production, $\mathrm{M}$ - mixed, $\mathrm{Av}$ - mean, me - median, the highest values are bolded Source: Our own calculation based on FADN data

$\mathrm{H}_{1}$ is that the distributions are different. By determining the value of the test statistic, we determine on its basis the probability value $p$, which we compare with significance level $\alpha$. If $\mathrm{p}=<\alpha$, then we reject $\mathrm{H}_{0}$ in favor of the hypothesis $\mathrm{H}_{1}$, and if $\mathrm{p}>\alpha$ there is no reason to reject $\mathrm{H}_{0}$.

Analyzing the results of the Mann-Whitney $U$ test (see Table 4), we note that in 2009-2014 the location of the farm in LFA is statistically significantly differentiating the financial efficiency of farms measured by the return on assets (ROA) as well as measured by the return on equity (ROE). Referring to the median values in Table 4, we see that medians for non-LFA farms are higher than LFA, which means that an LFA farm is less profitable than a non-LFA one. Based on the results presented in Table 4, we can confirm the validity of hypothesis H1 that in Poland, farms located on LFAs are significantly less profitable than farms located in favorable areas.

Tables 5 and 6 present differences between profitability indicators between production specialties - farms located on less favored areas (LFAs) and areas that may be described as normal conditions (in short: further as non-LFAs). The Kruskal-Wallis test was used here. Respectively, means and medians were presented. Types of farming (TF) that are used for
FADN typologies were aggregated ${ }^{1}$. Such a form of aggregation of FADN types of farming is more useful for highlighting the potential differences between the main orientations of production. In 2009 and 2014 there were significant and noticeable downturns in agriculture (depicted by, inter alia, "Syntetyczny Wskaźnik Koniunktury w Rolnictwie," Ang. Synthetic Economic Indicator in Agriculture, SKWR). In particular, farms representing "mixed production" were most severely affected by economic downturns in 2009 and 2014. It should be noted that differences between types were statistically significant ( $p$-value $<0,001$ ), both for a farms located on less favored and "normal" areas. Thus, hypothesis H2 (in LFA and nonLFA areas farms with an orientation of plant production as described by the highest - statistically significant financial effectiveness/profitability) may be verified positively.

1 The various production types according to TF8 FADN typology have been grouped as follows: "Crop"(TF1 Field crops, TF2 Horticulture, or TF4 - Other Permanent Crops ), "Livestock" (TF5 Milk, TF6 Other Grazing Livestock, or TF7 Granivores) and "Mixed" (TF8 Mixed). 
Table 6. Differences between profitability indicators between productions specialties and farms not located in less-favored areas.

\begin{tabular}{|c|c|c|c|c|c|c|c|}
\hline & & \multicolumn{3}{|c|}{ ROA } & \multicolumn{3}{|c|}{ ROE } \\
\hline & & $\mathrm{C}$ & $\mathrm{L}$ & M & $\mathrm{C}$ & $\mathrm{L}$ & M \\
\hline \multirow{3}{*}{2009} & $\mathrm{Me}$ & $-0,34$ & $\mathbf{0 , 3 7}$ & $-2,50$ & $-0,86$ & 0,04 & $-3,10$ \\
\hline & Av & $-0,40$ & 0,11 & $-2,17$ & $-0,61$ & $\mathbf{0 , 0 7}$ & $-2,30$ \\
\hline & & \multicolumn{3}{|c|}{ chi-squared $=66,995, \mathrm{df}=2, \mathrm{p}$-value $<0,001$} & \multicolumn{3}{|c|}{ chi-squared $=57,32, \mathrm{df}=2, \mathrm{p}$-value $<0,001$} \\
\hline \multirow{3}{*}{2010} & $\mathrm{Me}$ & 2,35 & 1,62 & $-0,38$ & 2,31 & 1,49 & $-0,51$ \\
\hline & Av & 2,22 & 1,13 & $-0,75$ & 2,29 & 1,17 & $-0,77$ \\
\hline & & \multicolumn{3}{|c|}{ chi-squared $=167,8, \mathrm{df}=2, \mathrm{p}$-value $<0,001$} & \multicolumn{3}{|c|}{ chi-squared $=158,64, \mathrm{df}=2, \mathrm{p}$-value $<0,001$} \\
\hline \multirow{3}{*}{2011} & $\mathrm{Me}$ & 2,80 & 2,00 & 0,30 & 2,76 & 1,91 & 0,21 \\
\hline & Av & 2,59 & 1,94 & $-0,14$ & 2,73 & 2,00 & $-0,14$ \\
\hline & & \multicolumn{3}{|c|}{ chi-squared $=234,03, \mathrm{df}=2, \mathrm{p}$-value $<0,001$} & \multicolumn{3}{|c|}{ chi-squared $=228,98, \mathrm{df}=2, \mathrm{p}$-value $<0,001$} \\
\hline \multirow{3}{*}{2012} & $\mathrm{Me}$ & 2,70 & 1,57 & 0,59 & 2,71 & 1,44 & 0,46 \\
\hline & Av & 2,44 & 1,28 & 0,17 & 2,56 & 1,30 & 0,19 \\
\hline & & \multicolumn{3}{|c|}{ chi-squared $=90,106, \mathrm{df}=2, \mathrm{p}$-value $<0,001$} & \multicolumn{3}{|c|}{ chi-squared $=85,215, \mathrm{df}=2, \mathrm{p}$-value $<0,001$} \\
\hline \multirow{3}{*}{2013} & $\mathrm{Me}$ & 1,53 & 1,19 & $-0,45$ & 1,40 & 1,00 & $-0,69$ \\
\hline & Av & 1,34 & 1,05 & $-0,83$ & 1,40 & 1,05 & $-0,90$ \\
\hline & & \multicolumn{3}{|c|}{ chi-squared $=98,915, \mathrm{df}=2, \mathrm{p}$-value $<0,001$} & \multicolumn{3}{|c|}{ chi-squared $=96,594, \mathrm{df}=2, \mathrm{p}$-value $<<0,001$} \\
\hline \multirow{3}{*}{2014} & $\mathrm{Me}$ & 0,21 & 0,54 & $-1,31$ & 0,24 & 0,56 & $-1,36$ \\
\hline & Av & $-0,06$ & 0,37 & $-1,67$ & 0,09 & $\mathbf{0 , 5 1}$ & $-1,61$ \\
\hline & & \multicolumn{3}{|c|}{ chi-squared $=82,717, \mathrm{df}=2, \mathrm{p}$-value $<0,001$} & \multicolumn{3}{|c|}{ chi-squared $=81,419, \mathrm{df}=2, \mathrm{p}$-value $<<0,001$} \\
\hline
\end{tabular}

Note: As per the previous table

Source: Our own calculation based on FADN data

Respectively, in all groups and years, profitability levels of farms located on non-LFAs were significantly higher than of those farms that have to deal with more difficult external determinants (i.e., LFA). This corresponds to the $\mathrm{H} 1$ hypothesis that refers to differences in profitability between farms located on LFAs and non-LFAs. A plethora of empirical studies [36-38] included a set of determinants that significantly affect various profitability indicators. They usually employed dummy variables related to the region that seemed to be statistically significant. In particular, "field crop" farms benefited from significant support in the form of direct payments and subsidies from the second pillar of the Common Agricultural Policy (CAP). Farms with livestock specialization were able to cushion the effects of unfavorable economic conditions. Additionally, comparing medians and means between "livestock specialization" in LFA and non-LFA farms in each year indicate a relatively small difference in the level of profitability. This resulted from a relatively industrial (in buildings) type of farming (excluding cattle grazing on grasslands). Location on LFAs cannot be treated as a strong barrier to generating high profitability for farms specialized in livestock production, in particular those not affected strongly by characteristics of the rural landscape [e.g. 38]. As for "mixed type," the problem is more complex and this requires a more detailed assessment of the share of individual production branches or the use of measures of product diversification (e.g., H-H index, entropy indicators).

The share of LFA farms that fulfill inequality ROE $>\mathrm{ROA}$ is different than in the case of non-LFA households (see Table 7).

The differences have appeared to be significant since 2011. In 2009 and 2010 the impact of external factors (related to sectoral business outlook) was evident, thus differences in financial efficiency between LFA and non-LFA farms were partially masked/offset. It suggests that LFA farms may have to face difficulties in applying for external financial sources that negatively influence their growth. In the case of efficiency measured by inequality $\mathrm{ROE}>\mathrm{ROA}$, we note that the location of a farm in LFA significantly statistically differentiates this efficiency between 2011 and 2014 (based on U Manna-Whitney test results; see Table 7).

The differences between profitability indicators between production specialties for farms located on LFAs and farms not located on LFAs are presented in Tables 8 and 9. That was statistically significant and 
Table 7. The share of entities that fulfill inequality ROE $>$ ROA in the group of LFA and non-LFA households.

\begin{tabular}{|c|c|c|c|c|c|}
\hline \multirow{2}{*}{ Specification } & \multicolumn{2}{|c|}{ Average } & \multicolumn{2}{|c|}{ SD } & $\begin{array}{c}\text { Significance of difference ROE }>\text { ROA } \\
\text { (p-value) } * *\end{array}$ \\
\cline { 2 - 5 } & LFA & non - LFA & LFA & non - LFA & 0,791 \\
\hline 2009 & 0,272 & 0,275 & 0,445 & 0,446 & 0,237 \\
\hline 2010 & 0,315 & 0,326 & 0,465 & 0,469 & 0,028 \\
\hline 2011 & 0,316 & 0,337 & 0,465 & 0,473 & 0,000 \\
\hline 2012 & 0,299 & 0,332 & 0,458 & 0,471 & 0,018 \\
\hline 2013 & 0,268 & 0,288 & 0,443 & 0,453 & 0,000 \\
\hline 2014 & 0,288 & 0,335 & 0,453 & 0,472 & $\mathbf{0 , 0 0 0}$ \\
\hline
\end{tabular}

Note: **U Mann-Whitney test, years with differences that were significant at the $5 \%$ level are shaded

Source: Our own calculation based on FADN data

Table 8. Differences between profitability indicators between production specialties and farms located in less-favored areas.

\begin{tabular}{|c|c|c|c|c|}
\hline & & \multicolumn{3}{|c|}{$\mathrm{ROE}>\mathrm{ROA}$} \\
\hline & & $\mathrm{C}$ & $\mathrm{L}$ & M \\
\hline \multirow{3}{*}{2009} & $\mathrm{Me}$ & 0 & $\mathbf{0}$ & 0 \\
\hline & Av & 0,28 & 0,31 & 0,19 \\
\hline & & \multicolumn{3}{|c|}{$\begin{array}{c}\text { chi-squared }=68,213, \mathrm{df}=2, \\
\text { p-value }<0,001\end{array}$} \\
\hline \multirow{3}{*}{2010} & $\mathrm{Me}$ & $\mathbf{0}$ & 0 & 0 \\
\hline & $\mathrm{Av}$ & 0,36 & 0,35 & 0,22 \\
\hline & & \multicolumn{3}{|c|}{$\begin{array}{c}\text { chi-squared }=91,353, \mathrm{df}=2 \\
\text { p-value }<0,001\end{array}$} \\
\hline \multirow{3}{*}{2011} & $\mathrm{Me}$ & 0 & $\mathbf{0}$ & 0 \\
\hline & Av & 0,34 & 0,36 & 0,22 \\
\hline & & \multicolumn{3}{|c|}{$\begin{array}{c}\text { chi-squared }=29,409, \mathrm{df}=2 \\
\text { p-value }<0,001\end{array}$} \\
\hline \multirow{3}{*}{2012} & $\mathrm{Me}$ & $\mathbf{0}$ & 0 & 0 \\
\hline & $\mathrm{Av}$ & 0,34 & 0,33 & 0,21 \\
\hline & & \multicolumn{3}{|c|}{$\begin{array}{c}\text { chi-squared }=76,984, \mathrm{df}=2, \\
\text { p-value }<0,001\end{array}$} \\
\hline \multirow{3}{*}{2013} & $\mathrm{Me}$ & 0 & $\mathbf{0}$ & 0 \\
\hline & $\mathrm{Av}$ & 0,29 & $\mathbf{0 , 3 1}$ & 0,17 \\
\hline & & \multicolumn{3}{|c|}{$\begin{array}{c}\text { chi-squared }=102,59, \mathrm{df}=2, \\
\text { p-value }<2,2 \mathrm{e}-16\end{array}$} \\
\hline \multirow{3}{*}{2014} & $\mathrm{Me}$ & 0 & $\mathbf{0}$ & 0 \\
\hline & $\mathrm{Av}$ & 0,29 & $\mathbf{0 , 3 3}$ & 0,19 \\
\hline & & \multicolumn{3}{|c|}{$\begin{array}{c}\text { chi-squared }=98,96, \mathrm{df}=2 \\
\text { p-value }<<0,001\end{array}$} \\
\hline
\end{tabular}

Note: $\mathrm{C}$ - crop production, $\mathrm{L}$ - livestock production, $\mathrm{M}$ - mixed, Av - mean, me - median; the highest values are bolded

Source: Our own calculations based on FADN data
Table 9. Differences between profitability indicators between productions specialties and farms not located in less-favored areas.

\begin{tabular}{|c|c|c|c|c|}
\hline & & \multicolumn{3}{|c|}{$\mathrm{ROE}>\mathrm{ROA}$} \\
\hline & & $\mathrm{C}$ & $\mathrm{L}$ & M \\
\hline \multirow{3}{*}{2009} & $\mathrm{Me}$ & 0 & $\mathbf{0}$ & 0 \\
\hline & $\mathrm{Av}$ & 0,28 & 0,32 & 0,23 \\
\hline & & \multicolumn{3}{|c|}{$\begin{array}{c}\text { chi-squared }=20,925, \mathrm{df}=2, \\
\text { p-value }<0,001\end{array}$} \\
\hline \multirow{3}{*}{2010} & $\mathrm{Me}$ & $\mathbf{0}$ & 0 & 0 \\
\hline & $\mathrm{Av}$ & 0,36 & 0,35 & 0,20 \\
\hline & & \multicolumn{3}{|c|}{$\begin{aligned} \text { chi-squared } & =50,757, \mathrm{df}=2, \\
\text { p-value } & =9,513 \mathrm{e}-12\end{aligned}$} \\
\hline \multirow{3}{*}{2011} & $\mathrm{Me}$ & 0 & 0 & 0 \\
\hline & $\mathrm{Av}$ & 0,36 & 0,36 & 0,28 \\
\hline & & \multicolumn{3}{|c|}{$\begin{array}{c}\text { chi-squared }=95,356, \mathrm{df}=2, \\
\text { p-value }<0,001\end{array}$} \\
\hline \multirow{3}{*}{2012} & $\mathrm{Me}$ & 0 & 0 & 0 \\
\hline & $\mathrm{Av}$ & 0,37 & 0,33 & 0,28 \\
\hline & & \multicolumn{3}{|c|}{$\begin{array}{c}\text { chi-squared }=26,291, \mathrm{df}=2, \\
\text { p-value }<0,001\end{array}$} \\
\hline \multirow{3}{*}{2013} & $\mathrm{Me}$ & $\mathbf{0}$ & 0 & 0 \\
\hline & $\mathrm{Av}$ & 0,31 & 0,30 & 0,24 \\
\hline & & \multicolumn{3}{|c|}{$\begin{array}{c}\text { chi-squared }=23,381, \mathrm{df}=2, \\
\text { p-value }<0,001\end{array}$} \\
\hline \multirow{3}{*}{2014} & $\mathrm{Me}$ & 0 & $\mathbf{0}$ & 0 \\
\hline & $\mathrm{Av}$ & 0,36 & 0,38 & 0,24 \\
\hline & & \multicolumn{3}{|c|}{$\begin{array}{c}\text { chi-squared }=61,877, \mathrm{df}=2, \\
\text { p-value }=<0,001\end{array}$} \\
\hline
\end{tabular}

Note: As per the previous table

Source: Our own calculations based on FADN data 
Table 10. Dependencies between the type of less favored areas and fulfilling inequality ROE $>$ ROA.

\begin{tabular}{|c|c|c|c|}
\hline & \multicolumn{3}{|c|}{2009} \\
\hline & & $\mathrm{ROE}<\mathrm{ROA}$ & $\mathrm{ROE}>\mathrm{ROA}$ \\
\hline M & 0 & 78,4 & 21,6 \\
\hline \multirow[t]{3}{*}{ I } & 1 & 72,7 & 27,3 \\
\hline & \multicolumn{3}{|c|}{$\chi^{2}=1,6815, \mathrm{df}=1, \mathrm{p}$-value $=0,195$} \\
\hline & \multicolumn{3}{|c|}{2010} \\
\hline M & 0 & 83,9 & 16,1 \\
\hline \multirow[t]{3}{*}{ I } & 1 & 68,1 & 31,9 \\
\hline & \multicolumn{3}{|c|}{$\chi^{2}=13,909, \mathrm{df}=1, \mathrm{p}$-value $<0,001$} \\
\hline & \multicolumn{3}{|c|}{2011} \\
\hline M & 0 & 83,5 & 16,5 \\
\hline \multirow[t]{3}{*}{ I } & 1 & 68,1 & 31,9 \\
\hline & \multicolumn{3}{|c|}{$\chi^{2}=11,755, \mathrm{df}=1, \mathrm{p}$-value $<0,001$} \\
\hline & \multicolumn{3}{|c|}{2012} \\
\hline M & 0 & 85,0 & 15,0 \\
\hline \multirow[t]{3}{*}{ I } & 1 & 69,9 & 30,1 \\
\hline & \multicolumn{3}{|c|}{$\chi^{2}=11,558, \mathrm{df}=1, \mathrm{p}$-value $<0,001$} \\
\hline & \multicolumn{3}{|c|}{2013} \\
\hline M & 0 & 84,6 & 15,4 \\
\hline \multirow[t]{3}{*}{ I } & 1 & 73,0 & 27,0 \\
\hline & \multicolumn{3}{|c|}{$\chi^{2}=6,1525, \mathrm{df}=1, \mathrm{p}$-value $<0,013$} \\
\hline & \multicolumn{3}{|c|}{2014} \\
\hline M & 0 & 76,4 & 23,6 \\
\hline I & 1 & 71,1 & 28,9 \\
\hline & \multicolumn{3}{|c|}{$\chi^{2}=1,4185, \mathrm{df}=1, \mathrm{p}$-value $=0,234$} \\
\hline
\end{tabular}

Note: $\mathrm{M}$ - mountain areas, I - 'intermediate' LFAs; cross tables present the share (\%) of the number of farms in the total number of $\mathrm{M}$ and I households, respectively

Source: Our own calculations based on FADN data

confirmed by $p$-values ( $p$-value $<0,05$ ). Being located in mountainous areas means tackling barriers with productivity, in particular for crop production (types: TF1 "field crops," TF2 "horticulture," and TF4 "other permanent crops"). Moreover, farms located on lessfavored lowland areas were dominant. It should be noted that in the first and last years of the analyzed period, farms located in mountainous areas had significant difficulties in achieving the return on equity above the return on assets (ROE $>$ ROA). For example, in 2009 only $21 \%$ of entities could fulfill the aforesaid financial inequality, whereas in $201315 \%$ of farms succeeded in the return of equity below the return on assets. This should be compared with the situation of farms located on lowland LFAs, of which $27,0-31,9 \%$ were not able to generate ROE higher than ROA. This may be explained by two factors: 1) greater opportunities for organic farming and short supply chains and 2) the FADN database included only commodity farms (below the threshold of the economic size, 4000 EUR), and small quasi-social farms were excluded.

Finally, detailed analysis should focus on assessing associations between types of LFA and the fundamental criterion of financial efficiency, i.e., ROE higher than ROA. Results presented in Table 10 indicate in years 2010-2014 the type of less favored areas (mountain or lowland areas, described as "intermediate" LFAs) and fulfilling "profitability equation" (ROE $>$ ROA) are associated variables.

Empirical results of Enjolras and Sentis [39] indicate that the location of a farm was one of the determinants of crop purchase. French economics included a detailed set of control variables related to natural conditions, including altitude of farm households. Królczyk, Latawiec, and Kuboń [40] discussed possibilities of an increase in yields of main cereals in Poland. They noted that "the feasibility of increasing yields and sustainably increasing agricultural productivity in Poland is determined primarily by natural conditions (agro-ecological suitability)" (p. 667), underlining that the role of technical and technological factors cannot be neglected. They added that "an important aspect is also to limit degradation of the productive potential of soils" (p. 667). Journeaux [17] described the complex mechanism of how environmental constraints affect land prices. Niewęgłowska [41] identified chances and restrictions for farms situated in areas with environmental restrictions. Although the category of the zone of "environmental restriction" is not equal to less-favored areas, her conclusions are interesting. She found that farms located in the zone of environmental restrictions were characterized by higher farm incomes, economic size, and values of farm equity. Farm operators from this zone are more willing to use credits in the capital structure. Nevertheless, the research sample of the Polish Farm Accountancy Network also included commodity farm households.

\section{Conclusions}

Roughly $40 \%$ of the developing world's rural population inhabits LFAs, which are characterized by low agricultural potential because of limited and uncertain rainfall, poor soils, steep slopes, or other biophysical constraints, or also areas with high agricultural potential but with limited access to infrastructure and markets, low population density, or other socio-economic constraints [42]. As a result, these regions, characterized by extreme conditions, contribute significantly to agricultural and economic stagnation. The concept of LFAs is most often associated with unfavorable demographic structure (emigration, aging population), an inefficient agricultural sector, poor 
ecological situation, underdeveloped infrastructure, low levels of living and health, and peripheral and border areas. In the world literature, LFAs also refer to less developed areas such as the steppe areas in Asia, the desert regions of Africa, or the mountainous areas of Europe [25].

Assessing the impact of location on LFAs has some crucial implications for farm management. For example, Journeaux [17] indicated that "the implication of the impact of environmental constraints" on land values resulted in changes in both credit risk of farm production, and the credit risk for financial institutions" (p. 25).

By verifying hypothesis $\mathbf{H 1}$, we confirmed statistically that in Poland in 2009-2014 the farms located on LFAs significantly differentiate the financial efficiency of farms, and finally we verified that in Poland, farms located on LFAs are significantly less profitable than farms located in favorable areas. Using the Mann-Whitney U test we noticed that the location of farms in LFAs statistically significantly differentiate the financial efficiency of farms measured by the return on assets (ROA), as well as being measured by the return on equity (ROE). Using median values for non-LFA and LFA farms, we confirmed that farms located on LFAs are less profitable than on non-LFAs

Profitability of farms located on mountainous LFAs was even higher than in such entities on lowland LFAs (opportunities from organic farming/methodology of sampling).

By verifying hypothesis H2, we proved that farms located on LFAs that specialize in crop production are described by the highest profitability. Although the values of ROE and ROA for "livestock specialization" in farms in each of year was relatively smaller, results strongly support the statement that, in particular, "field crop" farms may survive and deal with income risks, benefiting from EU support (not only LFA payments but also direct payments within I Pillar of Common Agricultural Policy). Having analyzed the levels of profitability between three main types (crop, livestock, and mixed crop-livestock), we can conclude that maintaining the desired level of profitability by livestock farms may be achieved by more intensive animal production techniques and a stronger link to agri-food markets. Nevertheless, this problem requires deeper exploration, including the use of primary data (from survey-based techniques) and/or building in-depth regression models (based on FADN data).

By verifying hypothesis $\mathbf{H 3}$, we concluded that LFA farms use assets and financial resources less effectively than non-LFA farms.

From a scientific point of view, it seems to be important to examine what factors affected such low profitability of mixed-type farms located on the LFAs. Studies conducted in this area are still insufficient and a research gap exists. Comparing particular subgroups of farms (LFAs and non-LFAs) accompanied by a statistical assessment of differences may be a prerequisite for changes in the amount of LFA payments or some shifts in eligibility conditions.

Our results contribute to an ongoing discussion on the impact of natural conditions on economic and financial results of farms. Our dependencies are based on the category of location on LFAs, not LFA payments received. Our findings shed light not only on differences between farms located on LFAs and non-LFAs, but they focus on evaluating differences between particular subgroups of LFA typology and type of farming (crop, livestock, and mixed productions).

Analysis conducted within the following article has some limitations. At first, Polish FADN does not collect data about all farm households - farms at a size below 2 ESU are omitted while their share is $66 \%$ of all Polish households. Although research conducted is also based on simple statistical methods, it describes the phenomena correctly and provides presumptions for further studies. Our results may be treated as the starting point for more detailed empirical analyses.

An in-depth analysis of the impact of LFA on the financial performance of farms, recommended in future studies, should include a detailed panel model approach with a set of socio-demographic determinants and a nexus between farms and agricultural markets (including participation in integration structures, e.g., producer groups, agricultural cooperatives, and so on). The degree of diversification of farm production should be included as one potential control variable.

Differences in profitability should be taken into consideration; employing only net farm income or total output does not fully describe financial efficiency ("net" effect of external and internal factors).

Further studies should also indicate to what extent the environmental factors, independent of farm managers, determine the profitability of the farm, which may be the case when assessing the creditworthiness of farms and, perhaps, when setting the insurance rate, assuming modification in the agricultural insurance system.

From the standpoint of public policy, analysis of profitability of LFA and non-LFA farms may be a prerequisite for changing LFA payment rates. However, in this case it is necessary to develop the classification of farms located on LFAs.

Designating a system of LFA payments should be more flexible. A lump sum approach based on the fixed rate that is still used seems to be very simplistic. Unfortunately, in Poland agricultural accounting is not obligatory, and therefore only a small number (FADN participants and additional farms that keep accounting records) may report basic categories that are important for determining the level of payment for unfavorable natural external conditions. Given the fluctuation in profitability indicators for LFA farms, in long-term perspectives, proposals of income stabilization tools (following, for example, the Canadian approach so-called agri-stability) should be carefully analyzed. 
Monitoring $\mathrm{ROE}>\mathrm{ROA}$ inequality as a signaling financial leverage may be useful for farm crediting systems. A combined approach to farm economic situations (including net farm income) and financial performance may be a basis for potential changes in the system of the setting of rates of LFA payments. Particularly, the specific capital needs of the farm located in mountainous areas should be verified.

\section{Acknowledgements}

Our research was prepared within the statutory activities of Institute of Finance at Faculty of Economics and Sociology, University of Łódź and research task "Financial policy towards rural areas and agriculture in the changing conditions at the national, European and global levels" conducted by the Institute of Agricultural and Food Economics - National Research Institute.

\section{Conflict of Interest}

The authors declare no conflict of interest.

\section{References}

1. HILL B., BRADLEY D. Comparison Of Farmers' Incomes In The EU Member States Study, Directorate-General For Internal Policies Policy Department B: Structural And Cohesion Policies Agriculture And Rural Development, 2015.

2. RAHMAN S., HASAN M.K. Environmental constraints and profitability relationships in agriculture: a case study of wheat farming in Bangladesh. Journal of the Asia Pacific Economy, 16, (4), 630, 2011.

3. SHERLUND S.M., BARRETT C.B., ADESINA A.A. Smallholder technical efficiency controlling for environmental production conditions. Journal of Development Economics, 69, 851, 2002.

4. TERLUIN I.J., GODESCHALK F.E., VON MEYER H. AND STRIJKER D. Agricultural Income in Less Favoured Areas of the EC: A Regional Approach. Journal of Rural Studies 11 (2), 217, 1995.

5. DAX T., HELLEGERS P. Policies for less-favored areas. CAP Regimes and the European Countryside: Prospects for Integration between Agricultural, Regional and Environmental Policies, Wallingford: CAB International, 179, 2000.

6. DWYER J., BALDOCK D., BEAUFOY G., BENNETT H., LOWE P., WARD W. Comparative report by IEEP: Europe's Rural Futures - The Nature of Rural Development II, London, 2002.

7. DAX T., HOVORKA G. A holistic approach to mountain development research: Experiences from the Federal Institute for Less-Favoured and Mountainous Areas, Austria, Paper given at The Innovative Structures for the Sustainable Development of Mountainous Areas (ISDEMA) Conference, School of Agriculture, Aristotle University of Thessaloniki, 8-9 November 2002.
8. DAX T. The Redefinition of Europe's Less Favoured Areas. $3^{\text {rd }}$ Annual Conference 'Rural Development in Europe' - Funding European Rural Development in 2007-2013. London, 15-16 November 2005.

9. European Commission. Less-favoured areas scheme, Retrieved from https://ec.europa.eu/agriculture/ruraldevelopment-previous/2007-2013/less-favoured-areasscheme_pl (19.08.2017).

10. KULAWIK J., MAJEWSKI E., PAWŁOWSKA-TYSZKO J., WĄS, A., WIELICZKO B. Budgetary determinants of the competitiveness of agriculture (Budżetowe uwarunkowania konkurencyjności rolnictwa) [in:] The CAP and the competitiveness of the Polish and European food sector (WPR a konkurencyjność polskiego i europejskiego sektora żywnościowego) (ed. Kowalski A, Wigier M., Wieliczko B.). IERiGŻ-PIB, Warsaw, 28, 2014 [In Polish].

11. BERGER T., SCHREINEMACHERS P., WOELCKE J. Multi-agent simulation for the targeting of development policies in less-favored areas. Agricultural Systems, 88 (1), 28, 2006.

12. BIGMAN D. Globalization and the Developing Countries. Emerging Strategies for Rural Development and Poverty Alleviation. CAB International and ISNAR, Wallingford, 2002.

13. FAN S., CHAN-KANG C. Returns to investment in less-favored areas in developing countries: a synthesis of evidence and implications for Africa. Food Policy, 2004.

14. RUBEN R., KUYVENHOVEN A., HAZELL P. Investing in poor people in less-favored areas: institutions, technologies, and policies for poverty alleviation and sustainable resource use. Staying Poor: Chronic Poverty and Development Policy'at IDPM, University of Manchester, 7, 2003.

15. KUYVENHOVEN A. Creating an enabling environment: policy conditions for less-favored areas. Food Policy, 29 (4), 407, 2004.

16. DE JANVRY A., SADOULET E., ARANJO C. Geography of poverty: territorial growth and rural development. World Bank ABCDE Paper, Washington, DC, April 30, 2002.

17. JOURNEAUX P. The effect of environmental constraints on land prices. AGFIRST, 2015.

18. SOJKOVÁ Z., KROPKOVÁ Z., BENDA V. Slovak agricultural farms in different regions-comparison of efficiency. Zemedelska Ekonomika-Praha, 54 (4), 158, 2008.

19. ANDERSON D.J., KEATLEY P. What LFA beef and sheep farmers should do and why they should do it. In 83rd Annual Conference, March 30-April 1, Dublin, Ireland: No. 50930. Agricultural Economics Society, 2009.

20. PENDER J., HAZELL P. Focus 4. Promoting sustainable development in less-favored areas. International Food Policy Research Institute, Washington, 2000.

21. UEMATSU H., KHANAL A.R., MISHRA A.K, The impact of natural amenity on farmland values: A quantile regression approach. Land Use Policy, 33, 151, 2013.

22. PROGRAM. Rural Development Program for 2014-2020. (Program Rozwoju Obszarów Wiejskich na lata 2014-2020). The Ministry of Agriculture and Rural Development, Warsaw, 2017 [In Polish].

23. MATUSZAK-FLEJSZMAN A., HADRYJAŃSKA B., GÓRNA J. Changes in Environmental Management after Poland's Entry to the EU-the Example of the Dairy Sector. Polish Journal of Environmental Studies, 22 (3), 2013. 
24. GÓRAL J. Subsidies versus economics, finances, and income of farms. 2, IAFE-NRI Press, Warsaw 2016.

25. KLEPACKA-KOLODZIEJSKA D. Support for less favored areas as an instrument affecting the development of rural areas in Poland (Wsparcie obszarów o niekorzystnych warunkach gospodarowania jako instrument oddziałujący na rozwój obszarów wiejskich w Polsce). Folia Pomer. Univ. Technol. Stetin., Oeconomica, 268 (54), 45, 2009.

26. SUTKOWSKA B., ROZBICKI J., GOZDOWSKI D. Farming Systems in High Nature Value (HNV) Farmland: a Case Study of Wigry National Park, Poland. Polish Journal of Environmental Studies, 22 (2), 2013.

27. NEHRING R., GILLESPIE J., HALLAHAN CH., HARRIS J.M., ERICKSON K. What is driving the economic and financial success of US cow-calf operations? Agricultural Finance Review, 74, (3), 311, 2014.

28. NIEWĘGŁOWSKA G. The impact of payments for less-favored areas (LFA) on agricultural firms in Poland (Wpływ płatności dla obszarów o niekorzystnych warunkach gospodarowania (ONW) na gospodarstwa rolne Polsce), IERiGŻ-PIB, Warsaw 2008 [In Polish].

29. AGENCY OF RESTRUCTURING AND MODERNIZATION OF AGRICULTURE. Payments for areas with natural constraints or other specific restrictions (so-called LFA payments) - Basic information - campaign 2015 (Płatności dla obszarów z ograniczeniami naturalnymi lub innymi szczególnymi ograniczeniami (tzw. płatność ONW) - podstawowe informacje - kampania 2015) Retrieved from http:// www.arimr.gov.pl/pomoc-unijna/prow-2014-2020/ dzialanie-13-platnosci-dla-obszarow-z-ograniczeniaminaturalnymi-lub-innymi-szczegolnymi-ograniczeniamitzw-platnosc-onw-podstawowe-informacje/platnosci-dlaobszarow-z-ograniczeniami-naturalnymi-lub-innymiszczegolnymi-ograniczeniami-tzw-platnosc-onwpodstawowe-informacje-kampania-2015.html (19.08.2017) [In Polish].

30. KOPIŃSKI J. The impact of the CAP on the organization and economic effects of farms with different production directions (Wpływ WPR na organizacje i efekty ekonomiczne gospodarstw o różnych kierunkach produkcji). Annals SERiA, XIV (3), 197, 2012.

31. FADN (2017). Organisation of European FADN (Organizacja Europejskiego FADN). Retrived from: http://fadn.pl/organizacja/europejski-fadn/organizacjaeuropejskiego-fadn/(19.08.2017) [In Polish].

32. BARRY P.J., ELLINGER P.N. Financial Management in Agriculture. $7^{\text {th }}$ Edition. Upper Saddle River, NJ: PrenticeHall, 2012.
33. STEFANI G., GADANAKIS Y., LOMBARDI G.V., TIBERTI M. The impact of financial leverage on farms capacity to react to market shocks. Proceedings of European Association of Agricultural Economists (EAAE), International Congress, August 28-September 1, Parma, Italy, 2017.

34. LANGEMEIER M. Leverage and Financial Risk, "farmdoc daily". 6, 28, Department of Agricultural and Consumer Economics, the University of Illinois at UrbanaChampaign, February 12, 2016.

35. KOPIŃSKI A. Financial analysis of a group of companies with the standard systems of inequalities (Analiza finansowa grupy przedsiębiorstw za pomocą wzorcowych układów nierówności). Scientific Papers of the University of Szczecin (Zeszyty Naukowe Uniwersytetu Szczecińskiego) 768, Finance, Financial Markets, Insurance (Finanse, Rynki Finansowe, Ubezpieczenia). 3, 261, 2013 [In Polish].

36. MISHRA A.K., EL-OSTA H.S., STEELE C.J., Factors affecting the profitability of limited resource and other small farms. In: Agricultural Finance Review. 59, 78, 1999.

37. MISHRA A.K., HARRIS J.M., ERICKSON K.W., HALLAHAN CH., DETRE J.D. Drivers of agricultural profitability in the USA: An application of the Du Pont expansion method. Agricultural Finance Review. 72 (3), 325, 2012.

38. NEHRING R., GILLESPIE A.L., HALLAHAN CH., HARRIS J.M., ERICKSON K. What's Driving U.S. Broiler Farm Profitability? International Food and Agribusiness Management Review. 18 (A), 59, 2015.

39. ENJOLRAS G., SENTIS P. Crop insurance policies and purchases in France, Agricultural Economics 42, 475, 2011.

40. KRÓlCZYK J.B., LATAWIEC A.E., KUBOŃ M. Sustainable Agriculture - the Potential to Increase Wheat and Rapeseed Yields in Poland. Polish Journal of Environmental Studies. 23 (3), 663, 2014.

41. NIEWĘGŁOWSKA G. Chances and limitations of farms located in the area of environmental restrictions based on the data of the Polish FADN (Szanse i ograniczenia gospodarstw położonych w strefie ograniczeń środowiskowych na podstawie danych Polskiego FADN). Journal of Agribusiness and Rural Development. 2 (12), 147, 2009 [In Polish].

42. KEULEN H. Heterogeneity and density in less-favored areas. Agricultural Systems 88, 1, 2006. 
